Int. J. Dev. Biol. 49: 467-477 (2005)

doi: $10.1387 / \mathrm{ijdb} .052001 \mathrm{er}$

\title{
Balance between cell division and differentiation during plant development
}

\author{
ELENA RAMIREZ-PARRA\#, BÉNÉDICTE DESVOYES\# and CRISANTO GUTIERREZ* \\ Centro de Biologia Molecular "Severo Ochoa», CSIC, Universidad Autónoma de Madrid, Spain
}

\begin{abstract}
The processes which make possible that a cell gives rise to two daughter cells define the cell division cycle. In individual cells, this is strictly controlled both in time and space. In multicellular organisms extra layers of regulation impinge on the balance between cell proliferation and cell differentiation within particular ontogenic programs. In contrast to animals, organogenesis in plants is a post-embryonic process that requires developmentally programmed reversion of sets of cells from different differentiated states to a pluripotent state followed by regulated proliferation and progression through distinct differentiation patterns. This implies a fine coupling of cell division control, cell cycle arrest and reactivation, endoreplication and differentiation. The emerging view is that cell cycle regulators, in addition to controlling cell division, also function as targets for maintaining cell homeostasis during development. The mechanisms and cross talk among different cell cycle regulatory pathways are discussed here in the context of a developing plant.
\end{abstract}

KEY WORDS: cell cycle, development, Arabidopsis thaliana

\section{Introduction}

Progression through the cell division cycle requires duplication of the genetic material and the delivery of the newly duplicated genomes to the two daughter cells during mitosis. This occurs in coordination with increases in other cellular components and changes in cell architecture and it represents one of the key processes in living organisms. In addition to the temporal and spatial regulation of the cell division cycle, the acquisition of a multicellular body plan imposes extra layers of complexity and regulation. Multicellularity is probably one source of evolutionary differences in the regulation of cellular processes. In fact, it is more appropriate to consider the concept of cell proliferation, instead of cell division, since it includes cell cycle control itself, cell cycle arrest and reactivation, endocycle, cell differentiation and cell death. In addition, these processes considered at the cellular level must be coupled to the particular ontogenic program. Plants and animals have evolved very different developmental strategies. While organogenesis in animals occurs during embryogenesis, organ initiation and growth in plants is a post-embryonic and continuous process that occurs over the entire lifespan of the organism. This remarkable fact relies on the existence of stem cell niches, e.g. in the shoot and root apical meristems (Nakajima and Benfey, 2002; Weigel and Jurgens, 2002) that continuously provide new cells that eventually take specific differentiation patterns. A second aspect relevant for the present discussion is the ability of plants to regenerate. Cells in certain locations can dedifferentiate and revert to a totipotent (or pluripotent) state, proliferate in a highly controlled manner and take multiple cell fates to form an entire organ or adult plant.

These processes involve specific regulatory networks that impinge on cell proliferation. Thus, an increasing interest focuses on answering the question of whether our current concepts of cell cycle regulators define all what they really do. An emerging view is that cell cycle regulatory components, in addition to controlling cell cycle progression, also have some roles in the coordination of cell division in the context of a developing organism. Altering cell cycle control has profound consequences in organogenesis, although plants seem to be very tolerant to changes in the level of cell cycle regulators. Furthermore, disturbances in cell proliferation are not associated with programmed cell death or oncogenic transformation, as it occurs in animals. The mechanisms and cross talk among different regulatory pathways that impinge on cell proliferation during plant development are discussed in the paragraphs below.

Abbreviations used in this paper: ABA, abscisic acid; CDK, cyclin-dependent kinase; CK, cytokinin; RBR, retinoblastoma-related.

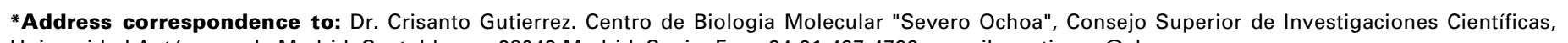
Universidad Autónoma de Madrid, Cantoblanco, 28049 Madrid, Spain. Fax+34-91-497-4799. e-mail: cgutierrez@cbm.uam.es

\# Note: These authors have contributed equally to this article. 


\section{The plant cell cycle machine}

Studies in single-cell model systems (yeast and mammalian cells in culture) have provided during the last two decades most of our current knowledge of molecular mechanisms regulating cell cycle transitions. Phylogenetic analysis of cell cycle regulators, together with molecular, cellular and genetic approaches, has revealed that the general strategies for the basic cell cycle machinery and control are highly conserved in all eukaryotes. Thus, experimental studies and the availability of genomic sequences of several plant species, most remarkably Arabidopsis thaliana (http:/ /www.arabidopsis.org/home.html; http://mips.gsf.de/proj/thal/db/ index.html), indicate that conservation of cell cycle regulators also occurs through the plant kingdom. Some exceptions and the presence of plant-specific cell cycle genes have been also found.

Cyclin-dependent kinases (CDK) are also the major drivers of plant cell cycle transitions. The Arabidopsis CDK family is a complex family of 12 members (Vandepoele, et al., 2002). CDKA is the typical PSTAIRE-containing CDK, homologous to yeast Cdc2 and necessary for G1/S and G2/M transitions. CDKB proteins are plant-specific CDKs that are expressed from $S$ through $M$ phase (B1; PPTALRE) and in G2 and M phases (B2; PPTTLRE).

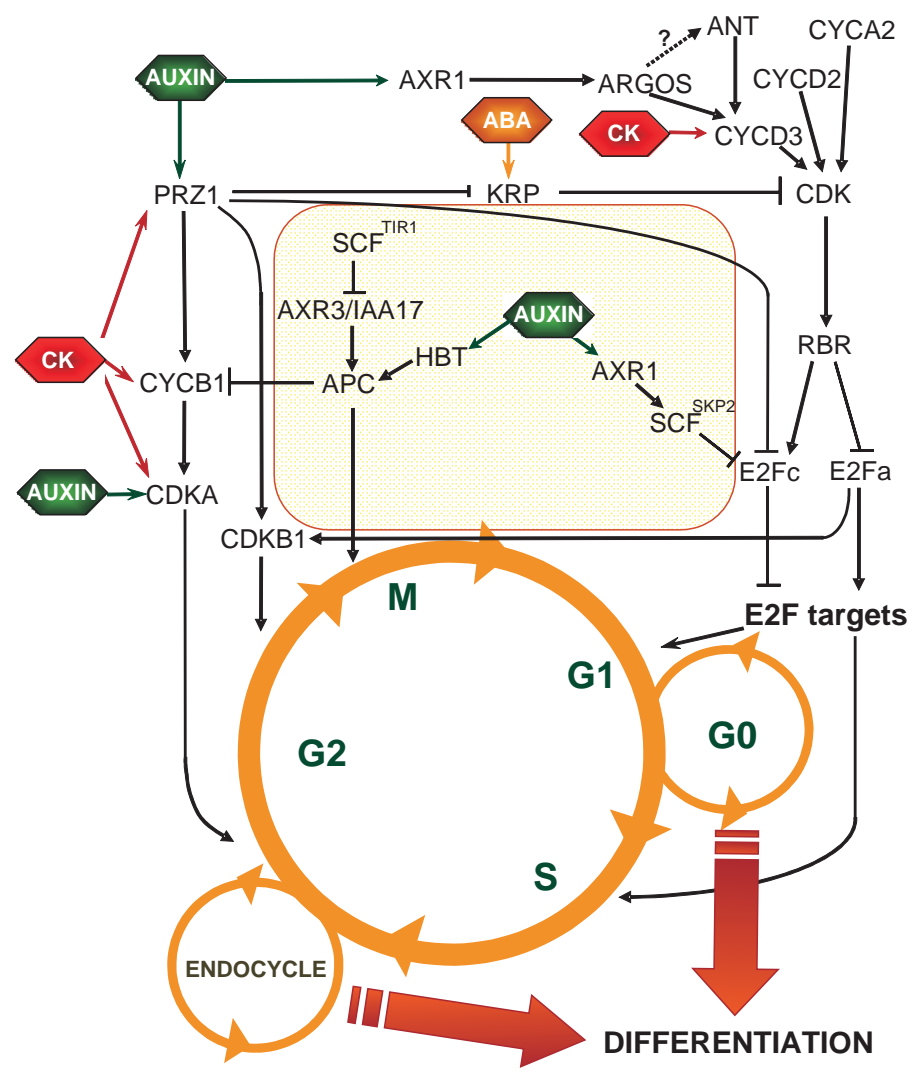

Fig. 1. Hormonal control of the level and/or activity of cell cycle regulatory components. CDK/cyclin complexes drive the G1/S and G2/M transitions. Hormone signaling affects either transcription of stability in several cell cycle regulators. This map includes information derived from different plant species or organs. Consequently, it may not apply in a general sense. The main message is to highlight the interconnections of different hormone signaling pathways with cell cycle transitions, mainly G1/S and G2/M. Abbreviations are given throughout the text.
It has been shown that CDKB1 is required for stomatal development (Boudolf, et al., 2004a). CDKC (PITAIRE) is a CHED-related kinase with no known cell cycle function. CDKD and CDKF function as a CDK-activating kinase (CAK). Cyclins (CYC) are the CDK activator subunits. More than 40 different cyclins have been identified in the Arabidopsis genome (Vandepoele, et al., 2002; Wang, et al., 2004). The main cyclins are 10 cyclins A, 9 cyclins B and 10 cyclins $D$, of which some of them will most likely be involved in cell cycle transitions. For a comprehensive account of these data, including extensive expression analysis in synchronized cells, which is out of the focus of this review, the reader is referred to previous reports (Menges, et al., 2002; Dewitte and Murray, 2003). CDK/cyclin activity also depends on the function CDK inhibitors (human p27Kip-related proteins; KRP), scaffold proteins (CKS) related to yeast Suc1 and regulatory kinases (WEE1; Vandepoele, etal., 2002) and phosphatases (CDC25-like; Landrieu, et al., 2004).

The role of individual CDK/cyclin complexes in vivo is far from being completely known, although increasing amount of information is becoming available from in vitro studies and expression studies. They seem to participate in, at least, three major cell cycle control points. One is the negative regulation of the retinoblastomarelated (RBR) protein by specific phosphorylation of $S$ or $T$ residues, although the consequences of this are not fully understood. RBR was originally identified in maize based on the ability of a plant DNA virus protein (RepA) to interact with RBR through a LXCXE amino acid motif (Xie, et al., 1995; Grafi, et al., 1996; Xie, et al., 1996). Later many different plant species (Dewitte and Murray, 2003), including Arabidopsis that encodes a single RBR gene (Ebel, et al., 2004), were shown to contain RBR-encoding genes. Plant RBR proteins share features of the three human members of the pocket protein family. RBR binds to and negatively regulates the activity of E2F/DP transcription factors. Arabidopsis contains six E2F (a through $\mathrm{f}$ ) and two DP ( $a$ and $b$ ) genes (letters are proposed instead of numbers since they are not orthologues of the human E2F1-7 and DP1-2 genes). In short, E2Fa, b and c contain DNA binding, DP heterodimerization, RBR interaction and transactivation domains (de Jager, et al., 2001; Mariconti, et al., 2002). The other three members, E2Fd, e and $f$ (also known as DEL2, 1 and 3, respectively) are homologues of the recently identified human E2F7 (Bracken, et al., 2004). They are atypical since they have a duplicated DNA binding domain and bind DNA without dimerizing with DP (de Jager, et al., 2001; Kosugi and Ohashi, 2002a; Mariconti, et al., 2002) and, at least in the case of E2Ff, do not interact with RBR (Ramirez-Parra, et al., 2004). E2F/ DP complexes typically control the expression of genes required for G1/Stransition and S-phase progression. Among these, PCNA, the DNA polymerase $\delta$ processivity factor (Kosugi and Ohashi, 2002b), the ribonucleotide reductase subunits (Chaboute, et al., 2000; Chaboute, et al., 2002), members of the pre-replication complexes (preRC) such as CDC6 (Castellano, et al., 2001), CDT1 (Castellano, et al., 2004) or MCM3 (Stevens, et al., 2002), among others (de Jager, et al., 2001; Kosugi and Ohashi, 2002b; RamirezParra, et al., 2003; Vlieghe, et al., 2003). Interestingly, genes required in other cell cycle phases, e.g. CDKB1, are also E2F/DP targets (Boudolf, et al., 2004b), or involved in metabolic processes not directly related to cell cycle progression, such as nitrogen assimilation (Vlieghe, et al., 2003) or cell wall expansion (RamirezParra, et al., 2004), are also E2F targets. Future studies using 
genomic approaches will certainly provide invaluable information on the involvement of E2F transcriptional network in regulating processes related to organogenesis and differentiation.

Another pathway where CDK/cyclin activity is likely crucial is the regulation of pre-RC function during initiation of DNA replication. Both CDC6 and CDT1 have been shown to be substrates for different CDK/cyclin complexes using recombinant proteins (Castellano, et al., 2001; Castellano, et al., 2004). In these cases, phosphorylation seems to be a necessary step to target these proteins for proteasome-mediated proteolysis, a mechanism that applies to other plant cell cycle regulators, e.g. E2Fc (del Pozo, et al., 2002a).

Transition through $\mathrm{G} 2$ and $\mathrm{M}$ is also controlled by the activity of various $\mathrm{CDK} /$ cyclin complexes. CDKB1, an E2F target gene maximally expressed in G2, stimulates G2/M progression and is important for the balance between dividing and endoreplicating cells (Boudolf, et al., 2004b). Other late G2/M functions, for example arrangement of the pre-prophase band, also require a CDKA activity (Weingartner, et al., 2001). CYCB1 is the main activator driving G2/M transition and its level, as in other eukaryotes, is drastically reduced by proteolysis at the metaphase/anaphase transition. This occurs by the activity of the anaphase-promoting complex (APC; Capron, et al., 2003a). One major regulator of APC function is CCS52 (Cebolla, et al., 1999), a complex family of CDH1/FZR-related proteins (Tarayre, etal., 2004). Components of the APC complex, such as HOBBIT (CDC27-like; Blilou, et al., 2002) and NOMEGA (APC6/CDC16-like; Kwee and Sundaresan, 2003), have been identified.

Cytokinesis in plants is a rather unique process that implies the formation of a new cell wall to separate the two daughter cells. It involves a very complex interplay of membrane and cytoskeleton components where membrane trafficking and vesicle fusion are of primary importance (Carter, et al., 2004; Mayer and Jurgens, 2004).

\section{Hormonal control of cell cycle}

The control of cell proliferation and differentiation during development depends, in most cases, on the concerted action of plant hormones. Among them, auxins and cytokinins are the best documented and they can impinge directly on cell cycle regulators (Fig. 1). In addition, other hormones, e.g. abscisic acid, ethylene, jasmonic acid and brassinosteroids, whose action is much less well characterized, also have an impact on cell cycle progression and/ or arrest. These topics have been comprehensively reviewed recently (Stals and Inze, 2001; del Pozo, et al., 2005) and here we provide a short account of data relevant for the discussion below.

\section{Auxin}

Auxins play a crucial role in many aspects of plant development, cell division and expansion, apical dominance, lateral root development and vascular tissue development, among other processes (Leyser, 2002). The recent identification of mutants defective in auxin signaling indicates that specific proteasome-mediated degradation of proteins plays a central role in the transduction of the auxin signal (Dharmasiri and Estelle, 2002).

The $A X R 1$ gene, whose mutations result in a reduction in auxin response, encodes a protein required for modification of CUL1 protein, a structural component of the SCF complex (del Pozo and
Estelle, 1999; del Pozo, et al., 2002b). AXR1 is involved in the proteolysis of the transcription factors E2Fc (del Pozo, et al., 2002a) and AXR/IAA (Gray, et al., 2001). Moreover, it is also implicated in the degradation of many other target proteins, thus explaining the pleiotropic phenotype of the axr1 mutants. Mutations in the PROPORZ1 ( $P R Z 1$ ) gene, identified in a screening for defects in cell proliferation in the presence of auxin and cytokinin, produce a high tendency to form calli only in presence of either auxin or cytokinin (Sieberer, et al., 2003). The role of PRZ1, a transcriptional adapter protein that might regulate the expression of cell division genes, is to mediate the hormonal signal into the cell proliferation control. Consistent with a role of PRZ1 in cell proliferation, it is mainly expressed in shoot and root meristems and during lateral root development. In hormone free medium, expression of $\mathrm{B}$ - and D-types cyclins was reduced in the prz 1 mutant background while in hormone-containing medium E2FC and $C D K B 1 ; 1$ are up regulated leading to the formation of undifferentiated callus-like structures (Sieberer, et al., 2003).

$H O B B / T$ gene encodes a component of the APC complex. hobbit mutants, whose auxin response is partially impaired, have defects in cell division and cell differentiation. They are likely due to the stabilization of the AXR3/IAA17 transcription factor, one of the ubiquitin-dependent targets of the SCF ${ }^{\mathrm{TIR} 1}$ pathway (Blilou, et al., 2002). Anomalies similar to those observed in the hobbit mutants are also found in other auxin signaling mutants, e.g. axr6, monopteros and bodenlos. AXR6 encodes CUL1 that is part of SCF complexes involved in a variety of pathways and plays an important role in auxin response (Hellmann, et al., 2003). BODENLOS (BDL) and MONOPTEROS (MP) encode IAA12 and ARF5 proteins, respectively (Hardtke and Berleth, 1998; Hamann, et al., 2002).

Auxin is sufficient to up-regulate the CDKA; 1 expression, but the kinase activity and the subsequent entry into mitosis is only induced by the addition of cytokinin (Zhang, etal., 1996). However, there is direct evidence that auxin also regulates the expression of some regulatory subunits. Thus, alfalfa $C Y C A 2,2$ expression is induced by auxin and during lateral root initiation and elongation (Roudier, et al., 2003). Consistent with such expression pattern, CYCA2 has been involved in mitotic cycles but not in endocycles and cell differentiation.

\section{Cytokinins}

Cytokinins (CK) are implicated in essential plant growth-related processes, e.g. induction of cell division and shoot formation and development (Mok, 1994), activation of dormant lateral buds (Napoli, et al., 1999), delayed senescence (Gan and Amasino, 1995), among others.

Cytokinins regulate cell cycle progression both at the G1/S and G2/M transitions (Fig. 1). The transcriptional activation of CYCD3 by cytokinins is the main evidence for the involvement of cytokinin in G1/S regulation (Soni, et al., 1995). Furthermore, constitutive expression of $C Y C D 3 ; 1$ produces hormone-independent growth of Arabidopsiscalli (Riou-Khamlichi, etal., 1999). However, CKare also important in the regulation of G2/M transition. In cultured tobacco cells, which do not need CK for growth, endogenous CK concentration peaks around the $\mathrm{S}$ and $\mathrm{M}$ phases (Redig, et al., 1996). Lovastatin, an inhibitor of CK biosynthesis, blocks cells in mitosis and exogenous addition of CK bypasses this block, supporting the idea that $\mathrm{CK}$ levels are rate-limiting for the G2/M 
transition in tobacco cells (Laureys, et al., 1998). CK likely stimulates tyrosine dephosphorylation and subsequent activation of CDK(Zhang, et al., 1996). In tobacco, auxin application increases the amount of CDK protein, but only cytokinin-mediated dephosphorylation produces the activation of CDK (Zhang, et al., 1996).

Transgenic tobacco plants that overexpress constitutively cytokinin oxidases (CKXs) have low endogenous CK levels and present severe growth retardation (Werner, et al., 2001; Schmulling, 2002). These plants have smaller shoot apical meristems (SAM) and leaves with reduced size. These phenotypes are mainly due to a reduction in the rate of cell division. Cytokinin-deficient plants show enhanced meristematic activity leading to increased growth of the primary root. It has been proposed that CKXs control the exit of cells from root meristems. However, they act as positive regulators of cell division in the shoot apical meristem and as negative regulators in the root apical meristem (Werner, et al., 2003). The opposite phenotypes are observed in plants with increased levels of cytokinins, e.g., Arabidopsis-amp1 mutant plants (Chaudhury, et al., 1993), which show altered shoot apical meristems, increased cell proliferation, constitutive photomorphogenesis, early flowering time and transcriptional activation of cyclin CYCD3 (Riou-Khamlichi, et al., 1999; Nogué, etal., 2000). Likewise, mutants in the SUPERSHOOT (SPS ) gene, which also show increased levels of cytokinins, exhibit massive overproliferation of axilary meristems (Tantikanjana, et al., 2001).

\section{Other hormones}

Abscisic acid (ABA) is a general plant-growth inhibitor, involved in stress-response. ABA inhibits cell division and/or DNA synthesis in different plant cell types (Newton, 1977; Robertson, etal., 1990). The block occurs at the G1/S transition, likely by increasing the levels of KRP1 (Wang, etal., 1998). ABA also down regulates genes required for DNA replication, e.g., CDT1a, a component of the pre-RC complexes (Castellano, et al., 2004), topoisomerase I (Mudgil, et al., 2002), or TERT, required for telomere replication (Yang, etal., 2002). Other hormones such as brassinosteroids (BR; Clouse, 2002), gibberellins (GA; Davies, 1995), ethylene (ET; Guo and Ecker, 2004) and jasmonic acid (JA; Turner, et al., 2002) play specific roles in cell expansion (BR, GA), reproductive organ development (BR, GA, JA), wound response and senescence (JA) and cell proliferation (BR, ET). Microarray analysis of brassinosteroid-regulated genes shows deregulation of genes implicated in cell elongation and cell wall organization (Goda, et al., 2002). Brassinolide up-regulates expression of $C Y C D 3$ and $C D K B 1 ; 1$. In fact, BR addition can partially rescue the short-hypocotyl phenotype of plants with reduced levels of CDKB1;1 (Yoshizumi, et al., 1999; Hu, et al., 2000). JA blocks G1/ $\mathrm{S}$ and $\mathrm{G} 2 / \mathrm{M}$ transitions (Swiatek, et al., 2002) by unknown mechanisms. GA activates cell division (Asahina, et al., 2002) and in cooperation with ethylene and auxin, controls stomata development in the hypocotyl epidermis, a process that requires proliferation of precursor cells with limited stem cell potential (Saibo, et al., 2003). However, the information about the molecular interactions between these hormonal pathways with the cell cycle regulatory network is scattered and still poorly understood.

\section{Role of cell cycle regulators during development}

Studies in whole animal systems, e.g. mouse, Drosophila, are revealing unanticipated roles of cell cycle regulators during develop- ment that are cell- and organ-specific (Humbert, et al., 2004). The significant differences in organogenesis between animal (embryonic) and plants (post-embryonic) make comparable studies in genetically tractable plants systems, e.g. Arabidopsis, a powerful way to understand fundamental questions. This is a key question since development requires coordinated cell proliferation and, obviously, in the absence of a correct proliferation program development is impaired. Thus, what is the importance of cell division in development? Two opposing views have emerged over the years. One responds to the so-called "organismal theory" that claims that cell division simply follows a predetermined developmental program. The other is the "cellular theory" whereby cell division instructs organogenesis and development. Several examples exist that supports the view that a complex cross talk occurs between cell division control and development (Mizukami, 2001; Beemster, et al., 2003; Tsukaya, 2003). Recent evidence discussed below, indicate that the function of a variety of cell cycle regulators during cell cycle progression, arrest and reactivation is controlled in a cell type-, tissue- and organ-specific manner. In this way, cell cycle regulators may play roles as targets coupling cell proliferation with development and their appropriate function is crucial for patterning. In the paragraphs below we discuss the major phenotypic consequences of altering the function of different cell cycle regulatory components in the context of a whole plant.

\section{Cyclin-dependent kinases (CDK)}

Overexpression of Arabidopsis CDKA; 1 does not produce macroscopical changes while a dominant negative version inhibits cell division but not morphogenesis (Hemerly, et al., 1995). Similarly, CDKA overexpression in maize endosperm increases kinase activity but has no effect on endoreplication. On the contrary, overexpression of dominant negative version of CDKA reduces significantly ploidy level (Leiva-Neto, et al., 2004). CDKB1;1 is expressed in cells of the stomatal lineage. A decrease in the activity of CDKB1;1, a kinase controlling the balance between mitotically dividing cells and endoreplicating cells (Boudolf, et al., 2004b), impairs stomatal development by blocking meristemoid cell division (Boudolf, et al., 2004a). Interestingly, these cells still acquire stomatal cell identity, indicating that cell differentiation can be uncoupled from cell division. Mutations in the PROPORZ1 ( $P R Z 1$ ) gene, produces increased expression of $C D K B 1 ; 1$ and $E 2 F C$, leading to the formation of undifferentiated structures with proliferating cells (Harrar, et al., 2003). Arabidopsis hen3 (HUA ENHANCER3 ) mutants that lack CDKE, a homologue of human Cdk8, show improper specification of floral organs and termination of stem cell activity in the floral meristem (Wang and Chen, 2004).

\section{Cyclins}

Plants encode a complex set of cyclins, e.g. more than 40 in Arabidopsis (Wang, et al., 2004), which are considered to likely play distinct roles at different developmental stages. Overexpression of Arabidopsis CYCD2 increases growth rate by shortening the G1 phase in meristems (Cockcroft, et al., 2000). Overexpression of Arabidopsis CYCD3;1 allows cytokinin-independent growth and induces ectopic divisions producing leaves with more but smaller cells (Riou-Khamlichi, et al., 1999; Dewitte, et al., 2003). Interestingly, in spite of this sustained proliferative potential extra cells acquire a correct identity. In these plants, as well as in Arabidopsisplants expressing tobacco CYCA3;2 (Yu, etal., 2003), 
hyperplasia is associated with a suppression of the endocycle program associated with leaf development. This effect is also observed in trichomes, which become multicellular when $C Y C B 1,2$ is expressed (Schnittger, et al., 2002). Consistent with this, one of the defects in the Arabidopsis siamese mutants, which has multicellular trichomes (Walker, et al., 2000) is that $C Y C D 3 ; 1$ is up regulated. Furthermore, overexpression of $A$ INTEGUMENTA (ANT ; Mizukami and Fischer, 2000) or the auxin-inducible ARGOS (Hu, et al., 2003) genes increase organ size by inducing cell proliferation, an effect that is mediated by up-regulating $C Y C D 3$ expression. $C Y C A 3,2$, an early G1/S-activated gene, seems to be a functional homologue of animal cyclin $\mathrm{E}$ (Yu, et al., 2003). Thus, while reduction in $C Y C A 3,2$ expression produces defective embryos and impairs callus formation, overexpression leads to a reduction in cell differentiation potential and prevents plant regeneration from leaf discs. These data reinforce the importance of a correct balance between cell division and cell differentiation for a correct morphogenesis.

\section{CDK inhibitors}

Plants encode CDK inhibitors, the Kip-related (KRP) proteins, loosely related to the human p27 protein (De Veylder, et al., 2001), but plants lack homologues of the human p21 and INK4-related proteins. Arabidopsis KRP1-7 genes exhibit a highly specific expression pattern, suggesting distinct roles in cells with a different physiological status. Thus, KRP1 and KRP2 are expressed in endocycling cells while KRP4 and KRP5 are detected in mitotically dividing cells (Ormenese, et al., 2004). Overexpression of KRP1 or KRP2 inhibits cell division and changes morphogenesis of leaves that contain less but larger cells (Wang, et al., 2000; De Veylder, et al., 2001), an effect partially reversed by overexpression of an inducer of cell division, such as CYCD3 (Zhou, et al., 2003). Likewise, overexpression of tobacco CDK inhibitor (KIS1) reverses the altered leaf phenotype of plants expressing $C Y C D 3$ ectopically (Jasinski, et al., 2002). This indicates that a proper balance of cell division activity and cell cycle arrest is required to develop a correct morphogenetic pattern. Interestingly, the coupling of KRP1/2 and CYCD3 functions seems reminiscent of the situation found for p27 and cycD1 in mice (Tong and Pollard, 2001).

\section{Retinoblastoma-related (RBR) protein}

The in vivo roles of RBR (reviewed in Gutierrez, et al., 2002; Dewitte and Murray, 2003), one of the main targets of CDK/cyclin complexes (Nakagami, et al., 1999; Boniotti and Gutierrez, 2001; Nakagami, et al., 2002), have been elusive for the past years. Only recently, direct evidence of RBR as a negative regulator of cell proliferation has been obtained. Loss-of-function mutations in the $R B R$ gene results in an impairment to restricts mitosis in the haploid nuclei of the female gametophyte and endosperm nuclei, leading to a lethal phenotype (Ebel, et al., 2004). One of the functions of RBR is to contribute to repress the expression of genes regulated by the E2F/DP family of transcription factors. Initial studies, both in plants and animals, indicated that E2F/DP complexes regulated genes involved in cell cycle progression and DNA replication, e.g. PCNA (Egelkrout, et al., 2002; Kosugi and Ohashi, 2002b), MCM3 (Stevens, et al., 2002), CDC6 (Castellano, et al., 2001), CDT1 (Castellano, et al., 2004). However, an in silico search revealed genes in Arabidopsiscontaining at least one E2F/ DP binding site (TTTCCCGCC) in their promoters and belonging to a diverse collection of functional categories (Ramirez-Parra, et al., 2003). Transcriptomic analysis has expanded the set of potential target genes that are up or down regulated in plants with altered E2F/DP activity (Vlieghe, et al., 2003).

\section{E2F/DP transcription factors}

$\mathrm{E} 2 \mathrm{Fa}$, in cooperation with $\mathrm{DPa}$, is a regulator of $\mathrm{S}$-phase genes. When overexpressed ectopically, E2Fa/DPa induces cell division as well as endoreplication in organs such as leaves and hypocotyls (De Veylder, et al., 2002). E2Fa/DPa-mediated hyperplasia is eliminated by co-expression of a dominant negative mutant of CDKB1 while the endoreplication phenotype is enhanced (Boudolf, et al., 2004b).

E2Fc is a transcriptional repressor (del Pozo, et al., 2002a; Kosugi and Ohashi, 2002c) that cooperates in vivo with DPb (del Pozo et al., submitted) and is abundant in cell cycle arrested cells. Upon cell cycle stimulation, E2Fc (and possibly DPb) is phosphorylated by $\mathrm{CDK} /$ cyclin complexes and targeted for proteasomemediated degradation by SCFSKP2 complexes (del Pozo, et al., 2002a). Loss of E2Fc function produces organs with more but smaller cells, increases the expression of cell cycle genes and reduces the ploidy level strongly suggesting that E2Fc/DPb participates in the balance between cell proliferation and differentiation (del Pozo et al., submitted).

As mentioned above, three E2F family members in Arabidopsis (E2Fd-e-f, also named DEL2-1-3, respectively) are atypical since they act in a DP-independent manner. E2Fe (DEL1), which is expressed in dividing cells, is an inhibitor of the endocycle program. Leaves of E2Fe (DEL1) overexpressors show slightly reduced ploidy levels (Vlieghe, et al., 2005). Likewise, the reverse effect in the de/1-1 mutants was not very significant, reinforcing the idea that several genes regulate the balance between division and endoreplication. It is also interesting that E2Fe (DEL1) is able to reduce by half the endoreplication phenotype of E2Fa/DPa overexpressors, but not the hyperplastic phenotype (De Veylder, et al., 2002; Vlieghe, et al., 2005).

E2Ff has been shown to have an unanticipated role in regulating cell expansion once cells have abandoned the cell cycle (RamirezParra, et al., 2004). This occurs through down-regulating the expression of a set of genes, which are E2F targets, involved in cell wall biogenesis. Alterations in E2Fflevels produces changes in the size of organs where growth occurs essentially in one dimension, e.g. hypocotyls, roots, by changing cell size but not cell number, endoreplication level or the expression of cell cycle genes.

Therefore, it would be extremely informative to address the importance of the function of E2F complexes in different cell types for appropriate development and specific morphogenetic patterns in different organs.

\section{DNA replication factors}

Pre-replication complex (pre-RC) components are involved in initiation of DNA replication. A strict control on their availability restricts the triggering of more than one initiation event in each cell cycle, a process known as DNA replication licensing. Based on the information derived from studies with yeast and human cells, the pre-RC components are the origin recognition complex (ORC), a six-subunit complex, CDC6, CDT1, geminin and the minichromosome maintenance (MCM) complex, also a six-subunit complex (Bell and Dutta, 2002). 
Ectopic expression of CDC6 (Castellano, et al., 2001) or CDT1 (Castellano, et al., 2004) is sufficient to induce extra endocycles or cell division in a cell type-specific manner. A subset of leaf epidermal cells (the subsidiary cells in stomatal complexes that can give raise to secondary meristemoids and new stomata) are stimulated to proliferate while, trichome initials, that undergo differentiation-associated endocycles, trigger more endocycles (Castellano, et al., 2004). It is worth mentioning that when Cdt1 activity is increased in animals, similar consequences are obtained (Del Bene, et al., 2004). Gametophytic development (McCormick, 2004; Yadegari and Drews, 2004), for detailed reviews) and the early embryonic stages seem to be particularly sensitive to alterations in pre-RC function. Thus, mutations in the ORC2 gene leads to failure in nuclear division control (Collinge, et al., 2004), in the PROLIFERA (PRL) gene, that encodes MCM7, produces abnormal patterns of division planes (Holding and Springer, 2002) and in the CDC45 gene, which acts downstream pre-RC, to sterility (Stevens, et al., 2004).

It is likely that the molecular interactions of pre- $\mathrm{RC}$ components have been basically conserved in plants. However, current evidence reveals that altering pre-RC function has consequences beyond the cellular level. This strongly suggests that pre-RC is an important coordinator for the balance between cell proliferation, cell differentiation and patterning in a developmental context.

Upon completion of DNA replication during S-phase, cells face the decision of continuing in the cell cycle or exiting it in two possible ways: arrest and differentiate or switching to the endocycle program. Although endoreplication occurs in all eukaryotes (Edgar and Orr-Weaver, 2001), in plants is a typical feature of a large proportion of cells in the plant body. In fact, entering specific differentiation programs frequently requires or is associated with the acquisition of a certain polyploidy level. Disappearance of CYCB1 seems to be a prerequisite (Cebolla, et al., 1999). The switch to the endocycle program is regulated and/or affected by different gene products. CCS52, originally identified in alfalfa (Cebolla, et al., 1999), is a Fizzy-related (Fzr) activator of the anaphase-promoting complex (APC; Capron, et al., 2003b), most likely required for $C Y C B 1$ degradation. The relevance of $C Y C B 1$ in this switch derives from studies in Arabidopsis trichomes where ectopic expression of $C Y C B 1,2$ (but not $C Y C B 1 ; 1$ ) results in the appearance of multicellular structures, containing $2 \mathrm{C}$ nuclei, instead of the normal unicellular, polyploid branched trichomes (Schnittger, et al., 2002). Defects in other APC components also lead to accumulation of CYCB1 and, consequently, impair cells to develop mitosis correctly (Blilou, et al., 2002; Capron, etal., 2003b; Kwee and Sundaresan, 2003).

\section{Other genes that affect cell proliferation}

Other genes which are not direct cell cycle regulators have, nevertheless, a clear impact on cell proliferation and, consequently, on organogenesis. The root hairless2 (rh/2) and hypcotyl6 ( hyp6) mutants have a pleiotropic phenotype that include, among other features, dwarfism and a reduction in the ploidy level (Hartung, et al., 2002; Sugimoto-Shirasu, et al., 2002). These genes encode subunits of topoisomerase VI (TOPVI) and, surprisingly, other mutations in these genes have been identified in a screening for plants with altered sensitivity to brassinosteroids (Yin, et al., 2002). This unforeseen connection points to a complex interplay of hormone action with cell cycle control and development (see above discussion). This is further illustrated by the altered growth properties observed in mutants in the CONSTITUTIVE TRIPLE RESPONSE1 (CTR1)gene that also have an altered pattern of ploidy level in many organs (Gendreau, et al., 1999), although the mechanism is unknown. Overexpression of STRUWWELPETER (SWP) stimulates cell division in the leaf epidermis leading to altered organ structure (Autran, et al., 2002). Likewise, silencing of $D E K$ gene (a calpain homologue) expression in tobacco also produces extended cell division potential in the leaf epidermis (Ahn, et al., 2004). These plants have an altered pattern of expression of several cell cycle genes, suggesting that their availability may depend on calpain activity. Recent evidence point to the RBR/E2F pathway as one major regulator of cell division and differentiation potential in leaves as deduced from studies where RBR function is inactivated (Desvoyes et al., submitted). Several other genes (see the chapter on leaf morphogenesis) also impinge on the proliferative potential of cells although the molecular mechanisms behind are only beginning to be understood. For example, ANGUSTIFOLIA (AN; Tsuge, et al., 1996; Kim, et al., 2002) and ROTUNDIFOLIA (ROT3 and ROT4; Kim, et al., 1998; Narita, et al., 2004) regulate cell division along the two leaf axes and CINCINNATA (CIN), an Antirrhinum majus TCP family member, is required for cell cycle arrest (Nath, et al., 2003). A recent observation implicates the microRNA $J A W-D$ as a direct regulator of TCP genes (Palatnik, et al., 2003), which is a repressor of CYCD3 (Gaudin, et al., 2000). In other cases, circumstantial evidence implicates CYCD3 as a key regulatory component. Overexpression of ARGOS or AINTEGUMENTA (ANT; Mizukami and Fischer, 2000; $\mathrm{Hu}$, et al., 2003) increases organ size by stimulating cell division in all organs, an effect channeled, at least in part, by up regulation of $C Y C D 3$ expression. Further studies are required to establish the connection of these genetic pathways and their implications in the control of cell proliferation and differentiation potential.

\section{Developmentally regulated cell division potential}

The post-embryonic nature of organogenesis in plants and its continuous occurrence throughout the life of the organism are features with an obvious impact on the control of cell proliferation. Cells that abandon the meristems, where active cell division occurs, exit the cell cycle or remain in an extended cell cycle arrest, poorly understood in molecular terms. Then, they can be recruited to form the primordia of different organs, a process that depends on developmental cues, hormonal signals and environmental challenges. Organogenesis requires both an increase in cell number and hence reactivation of cell proliferation in a highly controlled manner and cell patterning followed by progression through distinct differentiation programs. Some of these aspects are discussed in detail elsewhere in this volume.

The transition from embryonic to vegetative growth is another key step. However, a striking feature of plants is their ability to regenerate. This implies that some cells in certain organs can dedifferentiate, revert to a totipotent stem cell state and proliferate in a controlled manner to originate entire organs or even somatic embryos. Furthermore, these embryos are fully proficient to originate an adult plant. Obviously, these steps have a direct relevance for the topic discussed in this review. The molecular basis for certain cells to revert to a proliferative state is largely unknown. 
However, indirect evidence suggests that resetting of their transcriptional program is likely a major event (Grafi and Avivi, 2004). PICKLE (PKL), a chromatin remodeling factor, is required to leave the embryonic fate through repression of $\angle E A F Y$ COTYLEDON ( $L E C 1$ and $\angle E C 2$ ) and FUSCA3 (FUS3) that confer embryonic identity (Dean Rider, et al., 2003). FUS3 is a regulator of ABA and GA biosynthesis (Gazzarrini and McCourt, 2003), stressing the key role of hormonal signaling in these early developmental steps. Conversely, ectopic expression of $\angle E C 1$ or $\angle E C 2$ induces embryo-like structures (Lotan, et al., 1998; Stone, et al., 2001). Furthermore, the chromatin assembly factor $1(\mathrm{CAF}-1)$ regulates the expression of WUSCHEL (WUS) and SCARECROW (SCR ) in the root apical meristem (Kaya, et al., 2001). Since MSI1, together with FASCIATA1 (FAS1) and FASCIATA2 (FAS2), constitutes CAF-1 and is a RBR-interacting protein (Ach, et al., 1997), the possibility exists that the RBR/E2F pathway might have a role in the embryonic/vegetative transition and vice versa.

Development of lateral roots constitutes an example of de novo organogenesis. One of the main effects of auxin in plant development is the induction of lateral roots (LR) by initiating pericycle cell division. Nevertheless, the molecular events that take place to develop these organs are only beginning to be understood (Casimiro, et al., 2003; Vanneste, et al., 2005). Most pericycle cells, as they leave the meristem, contains high levels of $C D K A$ and KRP2 transcripts, but lack $C Y C B 1$ (Himanen, et al., 2002). However, it was known that ectopic expression of $C Y C B 1$ is not sufficient to trigger LR formation (Doerner, et al., 1996). Current data also argue against the idea that pericycle cells had left the cell cycle and reached a differentiated stage. An alternative is that they remain with an extended meristematic activity (Casimiro, et al., 2003). Recently an inducible system has been designed in which the pericycle cells can be synchronized with the auxin transport inhibitor NPA and then these cells were able to re-enter into cell division upon auxin induction (Himanen, et al., 2002; Himanen, et al., 2004). Microarrays analysis has served to identify over 900 genes whose expression changes significantly upon LR induction (Himanen, et al., 2004). Auxin addition triggers several cell cycle genes expression progressively. $C Y C D 3 ; 1$, E2Fa and histone $\mathrm{H4}$ genes are quickly induced, $C D K B$ was also induced early, although later that the S-phase genes. In addition, the expression of CDK inhibitors KRP1 and KRP2 was rapidly and strongly reduced (Himanen, et al., 2002). Based solely on gene expression patterns LR development would consist of several stages: G1 block, auxin perception, transduction of auxin signal and progression through G1/S/G2 and eventually division.

A large number of mutants that show defects in LR formation have been identified (Casimiro, et al., 2003), many of these are affected in auxin signal transduction and several are involved in proteasome-mediated protein degradation. This is the case of the axr1 and tir1-1 mutants. TIR1 is an F-box protein that targets proteins for degradation through the proteasome (Gray, et al., 2001). The AUX/IAA17 protein, which is a transcriptional repressor of the auxin signal, is a well-characterized target of the SCF ${ }^{\text {TIR1 }}$ complex. Several of the aux/ iaa mutants also show severe growth defects, including those in LR formation (Dharmasiri and Estelle,

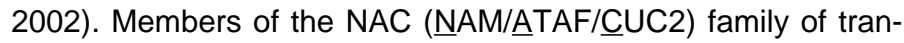
scription factors are involved in a variety of developmental processes (Olsen, et al., 2005). One of its members, NAC1 acts downstream of TIR1 and is required to trigger LR formation (Xie, et al., 2000). Transduction of auxin signal depends on SINAT5, a RING protein that negatively regulate NAC1 function by proteolysis (Xie, etal., 2002). Identifying the molecular links between proliferation control and auxin signaling during LR formation is therefore of primary importance.

It is clear that regulated cell proliferation is a prerequisite for development. Conversely, transduction of developmental cues is necessary to initiate differentiation processes ultimately leading to differentiated cells and organogenesis. In the case of plants, the continuous organogenetic activity during the entire life, the biology of stem cells and their ability to regenerate are also processes intimately related to cell proliferation control. Therefore, the main conclusion that we can draw from the studies discussed in the previous paragraphs is that we need to increase our efforts to determine the role of cell cycle regulators in whole organisms and in the context of development. Learning about the cross talk between cell proliferation and development will be extremely valuable not only to understand specific processes but also to answer basic questions in developmental biology.

\section{Acknowledgments}

This work has been partially supported by grants BMC2003-2131 (SpanishMinistry of Science and Technology) and 07B-53-2002(Comunidad Autonoma de Madrid) and by an institutional grant from Fundación Ramón Areces.

\section{References}

ACH, R.A., TARANTO, P. and GRUISSEM, W. (1997). A conserved family of WD-40 proteins binds to the retinoblastoma protein in both plants and animals. Plant Cell 9: 1595-1606.

AHN, J.W., KIM, M., LIM, J.H., KIM, G.T. and PAI, H.S. (2004). Phytocalpain controls the proliferation and differentiation fates of cells in plant organ development. Plant J. 38: 969-981.

ASAHINA, M., IWAI, H., KIKUCHI, A., YAMAGUCHI, S., KAMIYA, Y., KAMADA, H. and SATOH, S. (2002). Gibberellin produced in the cotyledon is required for cell division during tissue reunion in the cortex of cut cucumber and tomato hypocotyls. Plant Physiol. 129: 201-210.

AUTRAN, D., JONAK, C., BELCRAM, K., BEEMSTER, G.T., KRONENBERGER, J., GRANDJEAN, O., INZE, D. and TRAAS, J. (2002). Cell numbers and leaf development in Arabidopsis: a functional analysis of the STRUWWELPETER gene. EMBO J. 21: 6036-6049.

BEEMSTER, G.T., FIORANI, F. and INZE, D. (2003). Cell cycle: the key to plant growth control? Trends Plant Sci. 8: 154-158.

BELL, S.P. and DUTTA, A. (2002). DNA replication in eukaryotic cells. Annu. Rev. Biochem. 71: 333-374.

BLILOU, I., FRUGIER, F., FOLMER, S., SERRALBO, O., WILLEMSEN, V., WOLKENFELT, H., ELOY, N.B., FERREIRA, P.C., WEISBEEK, P. and SCHERES, B. (2002). The Arabidopsis HOBBIT gene encodes a CDC27 homolog that links the plant cell cycle to progression of cell differentiation. Genes Dev. 16: 25662575.

BONIOTTI, M.B. and GUTIERREZ, C. (2001). A cell-cycle-regulated kinase activity phosphorylates plant retinoblastoma protein and contains, in Arabidopsis, a CDKA/cyclin D complex. Plant J. 28: 341-350.

BOUDOLF, V., BARROCO, R., ENGLER JDE, A., VERKEST, A., BEECKMAN, T., NAUDTS, M., INZE, D. and DE VEYLDER, L. (2004a). B1-type cyclin-dependent kinases are essential for the formation of stomatal complexes in Arabidopsis thaliana. Plant Cel/ 16: 945-955.

BOUDOLF, V., VLIEGHE, K., BEEMSTER, G.T., MAGYAR, Z., ACOSTA, J.A., MAES, S., VAN DER SCHUEREN, E., INZE, D. and DE VEYLDER, L. (2004b). The plant-specific cyclin-dependent kinase CDKB1;1 and transcription factor E2Fa-DPa control the balance of mitotically dividing and endoreduplicating cells in Arabidopsis. Plant Cell 16: 2683-2692. 
BRACKEN, A.P., CIRO, M., COCITO, A. and HELIN, K. (2004). E2F target genes: unraveling the biology. Trends Biochem. Sci. 29: 409-417.

CAPRON, A., OKRESZ, L. and GENSCHIK, P. (2003a). First glance at the plant APC/ C, a highly conserved ubiquitin-protein ligase. Trends Plant Sci. 8: 83-89.

CAPRON, A., SERRALBO, O., FULOP, K., FRUGIER, F., PARMENTIER, Y., DONG, A., LECUREUIL, A., GUERCHE, P., KONDOROSI, E., SCHERES, B. and GENSCHIK, P. (2003b). The Arabidopsis anaphase-promoting complex or cyclosome: molecular and genetic characterization of the APC2 subunit. Plant Cell 15: 2370-2382.

CARTER, C.J., BEDNAREK, S.Y. and RAIKHEL, N.V. (2004). Membrane trafficking in plants: new discoveries and approaches. Curr. Opin. Plant Biol. 7: 701-707.

CASIMIRO, I., BEECKMAN, T., GRAHAM, N., BHALERAO, R., ZHANG, H., CASERO, P., SANDBERG, G. and BENNETT, M.J. (2003). Dissecting Arabidopsis lateral root development. Trends Plant Sci. 8: 165-171.

CASTELLANO, M.M., BONIOTTI, M.B., CARO, E., SCHNITTGER, A. and GUTIERREZ, C. (2004). DNA replication licensing affects cell proliferation or endoreplication in a cell type-specific manner. Plant Cel/ 16: 2380-2393.

CASTELLANO, M.M., DEL POZO, J.C., RAMIREZ-PARRA, E., BROWN, S. and GUTIERREZ, C. (2001). Expression and stability of Arabidopsis CDC6 are associated with endoreplication. Plant Cel/ 13: 2671-2686.

CEBOLLA, A., VINARDELL, J.M., KISS, E., OLAH, B., ROUDIER, F., KONDOROSI, A. and KONDOROSI, E. (1999). The mitotic inhibitor $\operatorname{ccs} 52$ is required for endoreduplication and ploidy-dependent cell enlargement in plants. EMBOJ.18: 4476-4484.

CHABOUTE, M.E., CLEMENT, B. and PHILIPPS, G. (2002). S phase and meristemspecific expression of the tobacco RNR1b gene is mediated by an E2F element located in the 5' leader sequence. J Biol. Chem. 277: 17845-17851.

CHABOUTE, M.E., CLEMENT, B., SEKINE, M., PHILIPPS, G. and CHAUBETGIGOT, N. (2000). Cell cycle regulation of the tobacco ribonucleotide reductase small subunit gene is mediated by E2F-like elements. Plant Cel/ 12: 1987-2000.

CHAUDHURY, A.M., LETHAM, S., CRAIG, S. and DENNIS, E.S. (1993). amp1: a mutant with high cytokinin levels and altered embryonic pattern, faster vegetative growth, constitutive photomorphogenesis and precocious flowering. Plant J. 4: 907-916.

CLOUSE, S.D. (2002). Brassinosteroid signal transduction: clarifying the pathway from ligand perception to gene expression. Mol. Cell 10: 973-982.

COCKCROFT, C.E., DEN BOER, B.G., HEALY, J.M. and MURRAY, J.A. (2000). Cyclin D control of growth rate in plants. Nature 405: 575-579.

COLLINGE, M.A., SPILLANE, C., KOHLER, C., GHEYSELINCK, J. and GROSSNIKLAUS, U. (2004). Genetic interaction of an origin recognition complex subunit and the Polycomb group gene MEDEA during seed development. Plant Cell 16: 1035-1046.

DAVIES, P. 1995. The plant hormones: Their nature, occurrence and functions. In Plant hormones: Physiology, biochemistry and molecular biology (ed. P.J. Davies), pp. 1-12. Kluwer Academic Publishers, Dordrecht (The Netherlands).

DEJAGER, S.M., MENGES, M., BAUER, U.M. and MURRAY, J.A. (2001). Arabidopsis E2F1 binds a sequence present in the promoter of S-phase-regulated gene AtCDC6 and is a member of a multigene family with differential activities. Plant Mol. Biol. 47: 555-568.

DE VEYLDER, L., BEECKMAN, T., BEEMSTER, G.T., DE ALMEIDA ENGLER, J., ORMENESE, S., MAES, S., NAUDTS, M., VANDERSCHUEREN, E., JACQMARD, A., ENGLER, G. and INZE, D. (2002). Control of proliferation, endoreduplication and differentiation by the Arabidopsis E2Fa-DPa transcription factor. EMBOJ.21: 1360-1368.

DE VEYLDER, L., BEECKMAN, T., BEEMSTER, G.T., KROLS, L., TERRAS, F., LANDRIEU, I., VAN DER SCHUEREN, E., MAES, S., NAUDTS, M. and INZE, D. (2001). Functional analysis of cyclin-dependent kinase inhibitors of Arabidopsis. Plant Cell 13: 1653-1668.

DEAN RIDER, S., JR., HENDERSON, J.T., JEROME, R.E., EDENBERG, H.J., ROMERO-SEVERSON, J. and OGAS, J. (2003). Coordinate repression of regulators of embryonic identity by PICKLE during germination in Arabidopsis. Plant J. 35: 33-43.

DEL BENE, F., TESSMAR-RAIBLE, K. and WITTBRODT, J. (2004). Direct interaction of geminin and Six3 in eye development. Nature 427: 745-749.

DEL POZO, J.C., BONIOTTI, M.B. and GUTIERREZ, C. (2002a). Arabidopsis E2Fc functions in cell division and is degraded by the ubiquitin-SCF(AtSKP2) pathway in response to light. Plant Cel/ 14: 3057-3071.

DEL POZO, J.C., DHARMASIRI, S., HELLMANN, H., WALKER, L., GRAY, W.M. and ESTELLE, M. (2002b). AXR1-ECR1-dependent conjugation of RUB1 to the Arabidopsis Cullin AtCUL1 is required for auxin response. Plant Ce// 14: 421-433.

DEL POZO, J.C. and ESTELLE, M. (1999). The Arabidopsis cullin AtCUL1 is modified by the ubiquitin-related protein RUB1. Proc. Natl. Acad. Sci. USA 96: 1534215347.

DEL POZO, J.C., LOPEZ-MATAS, M.A., RAMIREZ-PARRA, E. and GUTIERREZ, C. (2005). Hormonal control of the cell cycle. Physiol. Plant. 123: 173-183.

DEWITTE, W. and MURRAY, J.A. (2003). The plant cell cycle. Annu. Rev. Plant Biol. 54: 235-264.

DEWITTE, W., RIOU-KHAMLICHI, C., SCOFIELD, S., HEALY, J.M., JACQMARD, A., KILBY, N.J. and MURRAY, J.A. (2003). Altered cell cycle distribution, hyperplasia and inhibited differentiation in Arabidopsis caused by the D-type cyclin CYCD3. Plant Cell 15: 79-92.

DHARMASIRI, S. and ESTELLE, M. (2002). The role of regulated protein degradation in auxin response. Plant Mol. Biol. 49: 401-409.

DOERNER, P., JORGENSEN, J.E., YOU, R., STEPPUHN, J. and LAMB, C. (1996). Control of root growth and development by cyclin expression. Nature 380: 520523.

EBEL, C., MARICONTI, L. and GRUISSEM, W. (2004). Plant retinoblastoma homologues control nuclear proliferation in the female gametophyte. Nature 429: 776780.

EDGAR, B.A. and ORR-WEAVER, T.L. (2001). Endoreplication cell cycles: more for less. Cell 105: 297-306.

EGELKROUT, E.M., MARICONTI, L., SETTLAGE, S.B., CELLA, R., ROBERTSON, D. and HANLEY-BOWDOIN, L. (2002). Two E2F elements regulate the proliferating cell nuclear antigen promoter differently during leaf development. Plant Cell 14: 3225-3236.

GAN, S. and AMASINO, R.M. (1995). Inhibition of leaf senescence by autoregulated production of cytokinin. Science 270: 1986-1988.

GAUDIN, V., LUNNESS, P.A., FOBERT, P.R., TOWERS, M., RIOU-KHAMLICHI, C., MURRAY, J.A., COEN, E. and DOONAN, J.H. (2000). The expression of D-cyclin genes defines distinct developmental zones in snapdragon apical meristems and is locally regulated by the Cycloidea gene. Plant Physiol. 122: 1137-1148.

GAZZARRINI, S. and MCCOURT, P. (2003). Cross-talk in plant hormone signalling: what Arabidopsis mutants are telling us. Ann. Bot. (Lond) 91:605-612.

GENDREAU, E., ORBOVIC, V., HOFTE, H. and TRAAS, J. (1999). Gibberellin and ethylene control endoreduplication levels in the Arabidopsis thaliana hypocotyl. Planta 209: 513-516.

GODA, H., SHIMADA, Y., ASAMI, T., FUJIOKA, S. and YOSHIDA, S. (2002). Microarray analysis of brassinosteroid-regulated genes in Arabidopsis. Plant Physiol. 130: 1319-1334

GRAFI, G. and AVIVI, Y. (2004). Stem cells: a lesson from dedifferentiation. Trends Biotechnol. 22: 388-389.

GRAFI, G., BURNETT, R.J., HELENTJARIS, T., LARKINS, B.A., DECAPRIO, J.A., SELLERS, W.R. and KAELIN, W.G., JR. (1996). A maize cDNA encoding a member of the retinoblastoma protein family: involvement in endoreduplication. Proc. Natl. Acad. Sci. USA 93: 8962-8967.

GRAY, W.M., KEPINSKI, S., ROUSE, D., LEYSER, O. and ESTELLE, M. (2001). Auxin regulates SCF(TIR1)-dependent degradation of AUX/IAA proteins. Nature 414: 271-276.

GUO, H. and ECKER, J.R. (2004). The ethylene signaling pathway: new insights. Curr. Opin. Plant Biol. 7: 40-49.

GUTIERREZ, C., RAMIREZ-PARRA, E., CASTELLANO, M.M. and DEL POZO, J.C. (2002). G(1) to $S$ transition: more than a cell cycle engine switch. Curr. Opin. Plant Biol. 5: 480-486.

HAMANN, T., BENKOVA, E., BAURLE, I., KIENTZ, M. and JURGENS, G. (2002). The Arabidopsis BODENLOS gene encodes an auxin response protein inhibiting MONOPTEROS-mediated embryo patterning. Genes Dev. 16: 1610-1615.

HARDTKE, C.S. and BERLETH, T. (1998). The Arabidopsis gene MONOPTEROS encodes a transcription factor mediating embryo axis formation and vascular development. EMBO J. 17: 1405-1411.

HARRAR, Y., BELLEC, Y., BELLINI, C. and FAURE, J.D. (2003). Hormonal control of cell proliferation requires PASTICCINO genes. Plant Physiol. 132: 1217-1227. 
Cell cycle, differentiation and development in plants

HARTUNG, F., ANGELIS, K.J., MEISTER, A., SCHUBERT, I., MELZER, M. and PUCHTA, H. (2002). An archaebacterial topoisomerase homolog not present in other eukaryotes is indispensable for cell proliferation of plants. Curr. Biol. 12: 1787-1791.

HELLMANN, H., HOBBIE, L., CHAPMAN, A., DHARMASIRI, S., DHARMASIRI, N., DEL POZO, C., REINHARDT, D. and ESTELLE, M. (2003). Arabidopsis AXR6 encodes CUL1 implicating SCF E3 ligases in auxin regulation of embryogenesis. EMBO J. 22: 3314-3325.

HEMERLY, A., ENGLER JDE, A., BERGOUNIOUX, C., VAN MONTAGU, M., ENGLER, G., INZE, D. and FERREIRA, P. (1995). Dominant negative mutants of the $\mathrm{Cdc2}$ kinase uncouple cell division from iterative plant development. EMBOJ. 14: 3925-3936.

HIMANEN, K., BOUCHERON, E., VANNESTE, S., DE ALMEIDA ENGLER, J., INZE, D. and BEECKMAN, T. (2002). Auxin-mediated cell cycle activation during early lateral root initiation. Plant Cell 14: 2339-2351.

HIMANEN, K., VUYLSTEKE, M., VANNESTE, S., VERCRUYSSE, S., BOUCHERON, E., ALARD, P., CHRIQUI, D., VAN MONTAGU, M., INZE, D. and BEECKMAN, T. (2004). Transcript profiling of early lateral root initiation. Proc. Nat/. Acad. Sci. USA 101: 5146-5151.

HOLDING, D.R. and SPRINGER, P.S. (2002). The Arabidopsis gene PROLIFERA is required for proper cytokinesis during seed development. Planta 214: 373-382.

$\mathrm{HU}, \mathrm{Y}$., BAO, F. and LI, J. (2000). Promotive effect of brassinosteroids on cell division involves a distinct CycD3-induction pathway in Arabidopsis. Plant J. 24: 693-701.

HU, Y., XIE, Q. and CHUA, N.H. (2003). The Arabidopsis auxin-inducible gene ARGOS controls lateral organ size. Plant Cell 15: 1951-1961.

HUMBERT, P.O., BRUMBY, A.M., QUINN, L.M. and RICHARDSON, H.E. (2004). New tricks for old dogs: unexpected roles for cell cycle regulators revealed using animal models. Curr. Opin. Cell Biol. 16: 614-622.

JASINSKI, S., PERENNES, C., BERGOUNIOUX, C. and GLAB, N. (2002). Comparative molecular and functional analyses of the tobacco cyclin-dependent kinase inhibitor NtKIS1a and its spliced variant NtKIS1b. Plant Physiol. 130: 1871-1882.

KAYA, H., SHIBAHARA, K.I., TAOKA, K.I., IWABUCHI, M., STILLMAN, B. and ARAKI, T. (2001). FASCIATA genes for chromatin assembly factor-1 in arabidopsis maintain the cellular organization of apical meristems. Cel/ 104: 131-142.

KIM, G.T., SHODA, K., TSUGE, T., CHO, K.H., UCHIMIYA, H., YOKOYAMA, R., NISHITANI, K. and TSUKAYA, H. (2002). The ANGUSTIFOLIA gene of Arabidopsis, a plant CtBP gene, regulates leaf-cell expansion, the arrangement of cortical microtubules in leaf cells and expression of a gene involved in cell-wall formation. EMBO J. 21: 1267-1279.

KIM, G.T., TSUKAYA, H. and UCHIMIYA, H. (1998). The ROTUNDIFOLIA3 gene of Arabidopsis thaliana encodes a new member of the cytochrome P-450 family that is required for the regulated polar elongation of leaf cells. Genes Dev. 12: 23812391

KOSUGI, S. and OHASHI, Y. (2002a). E2Ls, E2F-like repressors of Arabidopsis that bind to E2F sites in a monomeric form. J Biol. Chem. 277: 16553-16558.

KOSUGI, S. and OHASHI, Y. (2002b). E2F sites that can interact with E2F proteins cloned from rice are required for meristematic tissue-specific expression of rice and tobacco proliferating cell nuclear antigen promoters. Plant J. 29: 45-59.

KOSUGI, S. and OHASHI, Y. (2002c). Interaction of the Arabidopsis E2F and DP proteins confers their concomitant nuclear translocation and transactivation. Plant Physiol 128: 833-843.

KWEE, H.S. and SUNDARESAN, V. (2003). The NOMEGA gene required for female gametophyte development encodes the putative APC6/CDC16 component of the Anaphase Promoting Complex in Arabidopsis. Plant J. 36: 853-866.

LANDRIEU, I., DA COSTA, M., DE VEYLDER, L., DEWITTE, F., VANDEPOELE, K., HASSAN, S., WIERUSZESKI, J.M., CORELLOU, F., FAURE, J.D., VAN MONTAGU, M., INZE, D. and LIPPENS, G. (2004). A small CDC25 dualspecificity tyrosine-phosphatase isoform in Arabidopsis thaliana. Proc. Natl. Acad. SCi. USA 101: 13380-13385.

LAUREYS, F., DEWITTE, W., WITTERS, E., VAN MONTAGU, M., INZE, D. and VAN ONCKELEN, H. (1998). Zeatin is indispensable for the G2-M transition in tobacco BY-2 cells. FEBS Lett. 426: 29-32.

LEIVA-NETO, J.T., GRAFI, G., SABELLI, P.A., DANTE, R.A., WOO, Y.M., MADDOCK, S., GORDON-KAMM, W.J. and LARKINS, B.A. (2004). A dominant negative mutant of cyclin-dependent kinase $A$ reduces endoreduplication but not cell size or gene expression in maize endosperm. Plant Cell 16: 1854-1869.
LEYSER, O. (2002). Molecular genetics of auxin signaling. Annu. Rev. Plant Biol. 53: 377-398.

LOTAN, T., OHTO, M., YEE, K.M., WEST, M.A., LO, R., KWONG, R.W., YAMAGISHI, K., FISCHER, R.L., GOLDBERG, R.B. and HARADA, J.J. (1998). Arabidopsis LEAFY COTYLEDON1 is sufficient to induce embryo development in vegetative cells. Cel/ 93: 1195-1205.

MARICONTI, L., PELLEGRINI, B., CANTONI, R., STEVENS, R., BERGOUNIOUX, C., CELLA, R. and ALBANI, D. (2002). The E2F family of transcription factors from Arabidopsis thaliana. Novel and conserved components of the retinoblastoma/ E2F pathway in plants. J Biol. Chem. 277: 9911-9919.

MAYER, U. and JURGENS, G. (2004). Cytokinesis: lines of division taking shape Curr. Opin. Plant Biol. 7: 599-604.

MCCORMICK, S. (2004). Control of male gametophyte development. Plant Cell 16 Suppl: S142-S153.

MENGES, M., HENNIG, L., GRUISSEM, W. and MURRAY, J.A. (2002). Cell cycleregulated gene expression in Arabidopsis. J Biol. Chem. 277: 41987-42002.

MIZUKAMI, Y. (2001). A matter of size: developmental control of organ size in plants. Curr. Opin. Plant Biol. 4: 533-539.

MIZUKAMI, Y. and FISCHER, R.L. (2000). Plant organ size control: AINTEGUMENTA regulates growth and cell numbers during organogenesis. Proc. Natl. Acad. Sci. USA 97: 942-947.

MOK, M.C. 1994. Cytokinins: chemistry, activity and function. In Cytokinins and plant development: an overview (ed. M. Mok DWS, MC), pp. 155-166. CRC, Boca Raton, FL.

MUDGIL, Y., SINGH, B.N., UPADHYAYA, K.C., SOPORY, S.K. and REDDY, M.K. (2002). Cloning and characterization of a cell cycle-regulated gene encoding topoisomerase I from Nicotiana tabacum that is inducible by light, low temperature and abscisic acid. Mol. Genet. Genomics 267: 380-390.

NAKAGAMI, H., KAWAMURA, K., SUGISAKA, K., SEKINE, M. and SHINMYO, A. (2002). Phosphorylation of retinoblastoma-related protein by the cyclin D/cyclindependent kinase complex is activated at the G1/S-phase transition in tobacco. Plant Cell 14: 1847-1857.

NAKAGAMI, H., SEKINE, M., MURAKAMI, H. and SHINMYO, A. (1999). Tobacco retinoblastoma-related protein phosphorylated by a distinct cyclin-dependent kinase complex with Cdc2/cyclin D in vitro. Plant J. 18: 243-252.

NAKAJIMA, K. and BENFEY, P.N. (2002). Signaling in and out: control of cell division and differentiation in the shoot and root. Plant Cell 14 Suppl: S265-276.

NAPOLI, C.A., BEVERIDGE, C.A. and SNOWDEN, K.C. (1999). Reevaluating concepts of apical dominance and the control of axillary bud outgrowth. Curr. Top. Dev. Biol. 44: 127-169.

NARITA, N.N., MOORE, S., HORIGUCHI, G., KUBO, M., DEMURA, T., FUKUDA, H., GOODRICH, J. and TSUKAYA, H. (2004). Overexpression of a novel small peptide ROTUNDIFOLIA4 decreases cell proliferation and alters leaf shape in Arabidopsis thaliana. Plant J. 38: 699-713.

NATH, U., CRAWFORD, B.C., CARPENTER, R. and COEN, E. (2003). Genetic control of surface curvature. Science 299: 1404-1407.

NEWTON, R.J. (1977). Absissic acid effects on fronds and roots of Lemna minor $L$. Am. J. Bot. 64: 45-49.

NOGUÉ, F., GRANDJEAN, O., CRAIG, S., DENNIS, E.S. and CHAUDHURY, A. (2000). Higher levels of cell proliferation rate and cycD3 expression in the Arabidopsis amp1 mutant. Plant Growth Regul. 32: 275-283.

OLSEN, A.N., ERNST, H.A., LEGGIO, L.L. and SKRIVER, K. (2005). NAC transcription factors: structurally distinct, functionally diverse. Trends Plant Sci. 10: 79-87.

ORMENESE, S., DE ALMEIDA ENGLER, J., DE GROODT, R., DE VEYLDER, L., INZE, D. and JACQMARD, A. (2004). Analysis of the spatial expression pattern of seven Kip related proteins (KRPs) in the shoot apex of Arabidopsis thaliana. Ann. Bot. (Lond) 93: 575-580.

PALATNIK, J.F., ALLEN, E., WU, X., SCHOMMER, C., SCHWAB, R., CARRINGTON, J.C. and WEIGEL, D. (2003). Control of leaf morphogenesis by microRNAs. Nature 425: 257-263.

RAMIREZ-PARRA, E., FRUNDT, C. and GUTIERREZ, C. (2003). A genome-wide identification of E2F-regulated genes in Arabidopsis. Plant J. 33: 801-811.

RAMIREZ-PARRA, E., LOPEZ-MATAS, M.A., FRUNDT, C. and GUTIERREZ, C. (2004). Role of an atypical E2F transcription factor in the control of Arabidopsis cell growth and differentiation. Plant Cel/ 16: 2350-2363. 
REDIG, P., SHAUL, O., INZE, D., VAN MONTAGU, M. and VAN ONCKELEN, H. (1996). Levels of endogenous cytokinins, indole-3-acetic acid and abscisic acid during the cell cycle of synchronized tobacco BY-2 cells. FEBSLett. 391: 175-180.

RIOU-KHAMLICHI, C., HUNTLEY, R., JACQMARD, A. and MURRAY, J.A. (1999). Cytokinin activation of Arabidopsis cell division through a D-type cyclin. Science 283: $1541-1544$.

ROBERTSON, J.M., YEUNG, E.C., REID, D.M. and HUBICK, K.T. (1990). Developmental responses to drought and absissic acid in sunflower roots. 2. Mitotic activity. J. Exp. Bot. 41: 339-350.

ROUdIER, F., FEDOROVA, E., LEBRIS, M., LECOMTE, P., GYORGYEY, J., VAUBERT, D., HORVATH, G., ABAD, P., KONDOROSI, A. and KONDOROSI, E. (2003). The Medicago species A2-type cyclin is auxin regulated and involved in meristem formation but dispensable for endoreduplication-associated developmental programs. Plant Physiol. 131: 1091-1103.

SAIBO, N.J., VRIEZEN, W.H., BEEMSTER, G.T. and VAN DER STRAETEN, D. (2003). Growth and stomata development of Arabidopsis hypocotyls are controlled by gibberellins and modulated by ethylene and auxins. Plant J. 33: 9891000

SCHMULLING, T. (2002). New Insights into the Functions of Cytokinins in Plant Development. J. Plant Growth Regul. 21: 40-49.

SCHNITTGER, A., SCHOBINGER, U., STIERHOF, Y.D. and HULSKAMP, M. (2002). Ectopic B-type cyclin expression induces mitotic cycles in endoreduplicating Arabidopsis trichomes. Curr. Biol. 12: 415-420.

SIEBERER, T., HAUSER, M.T., SEIFERT, G.J. and LUSCHNIG, C. (2003). PROPORZ1, a putative Arabidopsis transcriptional adaptor protein, mediates auxin and cytokinin signals in the control of cell proliferation. Curr. Biol. 13: 837842.

SONI, R., CARMICHAEL, J.P., SHAH, Z.H. and MURRAY, J.A. (1995). A family of cyclin $\mathrm{D}$ homologs from plants differentially controlled by growth regulators and containing the conserved retinoblastoma protein interaction motif. Plant Cell 7: 85-103.

STALS, H. and INZE, D. (2001). When plant cells decide to divide. Trends Plant SCI 6: 359-364

STEVENS, R., GRElON, M., VEZON, D., OH, J., MEYER, P., PERENNES, C., DOMENICHINI, S. and BERGOUNIOUX, C. (2004). A CDC45 homolog in Arabidopsis is essential for meiosis, as shown by RNA interference-induced gene silencing. Plant Cel/ 16: 99-113.

STEVENS, R., MARICONTI, L., ROSSIGNOL, P., PERENNES, C., CELLA, R. and BERGOUNIOUX, C. (2002). Two E2F sites in the Arabidopsis MCM3 promoter have different roles in cell cycle activation and meristematic expression. J Biol. Chem. 277: 32978-32984.

STONE, S.L., KWONG, L.W., YEE, K.M., PELLETIER, J., LEPINIEC, L., FISCHER, R.L., GOLDBERG, R.B. and HARADA, J.J. (2001). LEAFY COTYLEDON2 encodes a B3 domain transcription factor that induces embryo development. Proc. Natl. Acad. Sci. USA 98: 11806-11811.

SUGIMOTO-SHIRASU, K., STACEY, N.J., CORSAR, J., ROBERTS, K. and MCCANN, M.C. (2002). DNA topoisomerase VI is essential for endoreduplication in Arabidopsis. Curr. Biol. 12: 1782-1786.

SWIATEK, A., LENJOU, M., VAN BOCKSTAELE, D., INZE, D. and VANONCKELEN, H. (2002). Differential effect of jasmonic acid and abscisic acid on cell cycle progression in tobacco BY-2 cells. Plant Physiol. 128: 201-211.

TANTIKANJANA, T., YONG, J.W., LETHAM, D.S., GRIFFITH, M., HUSSAIN, M., LJUNG, K., SANDBERG, G. and SUNDARESAN, V. (2001). Control of axillary bud initiation and shoot architecture in Arabidopsis through the SUPERSHOOT gene. Genes Dev. 15: 1577-1588.

TARAYRE, S., VINARDELL, J.M., CEBOLLA, A., KONDOROSI, A. and KONDOROSI, E. (2004). Two classes of the CDh1-type activators of the anaphase-promoting complex in plants: novel functional domains and distinct regulation. Plant Cel/ 16: 422-434.

TONG, W. and POLLARD, J.W. (2001). Genetic evidence for the interactions of cyclin D1 and p27(Kip1) in mice. Mol. Cell Biol. 21: 1319-1328.

TSUGE, T., TSUKAYA, H. and UCHIMIYA, H. (1996). Two independent and polarized processes of cell elongation regulate leaf blade expansion in Arabidopsis thaliana (L.) Heynh. Development 122: 1589-1600.

TSUKAYA, H. (2003). Organ shape and size: a lesson from studies of leaf morpho- genesis. Curr. Opin. Plant Biol. 6: 57-62.

TURNER, J.G., ELLIS, C. and DEVOTO, A. (2002). The jasmonate signal pathway. Plant Cell 14 Suppl: S153-164.

VANDEPOELE, K., RAES, J., DE VEYLDER, L., ROUZE, P., ROMBAUTS, S. and INZE, D. (2002). Genome-wide analysis of core cell cycle genes in Arabidopsis. Plant Cell 14: 903-916.

VANNESTE, S., MAES, L., DE SMET, I., HIMANEN, K., NAUDTS, M., INZÉ, D. and BEECKMAN, T. (2005). Auxin regulation of cell cycle and its role during lateral root initiation. Physiol. Plant. 123: 139-146.

VLIEGHE, K., BOUDOLF, V., BEEMSTER, G.T., MAES, S., MAGYAR, Z., ATANASSOVA, A., DE ALMEIDA ENGLER, J., DE GROODT, R., INZE, D. and DE VEYLDER, L. (2005). The DP-E2F-like gene DEL1 controls the endocycle in Arabidopsis thaliana. Curr. Biol. 15: 59-63.

VLIEGHE, K., VUYLSTEKE, M., FLORQUIN, K., ROMBAUTS, S., MAES, S., ORMENESE, S., VAN HUMMELEN, P., VAN DE PEER, Y., INZE, D. and DE VEYLDER, L. (2003). Microarray analysis of E2Fa-DPa-overexpressing plants uncovers a cross-talking genetic network between DNA replication and nitrogen assimilation. J Cell Sci. 116: 4249-4259.

WALKER, J.D., OPPENHEIMER, D.G., CONCIENNE, J. and LARKIN, J.C. (2000) SIAMESE, a gene controlling the endoreduplication cell cycle in Arabidopsis thaliana trichomes. Development 127: 3931-3940.

WANG, G., KONG, H., SUN, Y., ZHANG, X., ZHANG, W., ALTMAN, N., DEPAMPHILIS C.W. and MA, H. (2004). Genome-wide analysis of the cyclin family in Arabidopsis and comparative phylogenetic analysis of plant cyclin-like proteins. Plant Physiol. 135: 1084-1099.

WANG, H., QI, Q., SCHORR, P., CUTLER, A.J., CROSBY, W.L. and FOWKE, L.C. (1998). ICK1, a cyclin-dependent protein kinase inhibitor from Arabidopsis thaliana interacts with both $\mathrm{Cdc} 2 \mathrm{a}$ and $\mathrm{CycD} 3$ and its expression is induced by abscisic acid. Plant J. 15: 501-510.

WANG, H., ZHOU, Y., GILMER, S., WHITWILL, S. and FOWKE, L.C. (2000) Expression of the plant cyclin-dependent kinase inhibitor ICK1 affects cell division, plant growth and morphology. Plant J. 24: 613-623.

WANG, W. and CHEN, X. (2004). HUA ENHANCER3 reveals a role for a cyclindependent protein kinase in the specification of floral organ identity in Arabidopsis. Development 131: 3147-3156

WEIGEL, D. and JURGENS, G. (2002). Stem cells that make stems. Nature 415: 751 754.

WEINGARTNER, M., BINAROVA, P., DRYKOVA, D., SCHWEIGHOFER, A., DAVID, J.P., HEBERLE-BORS, E., DOONAN, J. and BOGRE, L. (2001). Dynamic recruitment of $\mathrm{Cdc} 2$ to specific microtubule structures during mitosis. Plant Cell 13: $1929-1943$.

WERNER, T., MOTYKA, V., LAUCOU, V., SMETS, R., VAN ONCKELEN, H. and SCHMULLING, T. (2003). Cytokinin-deficient transgenic Arabidopsis plants show multiple developmental alterations indicating opposite functions of cytokinins in the regulation of shoot and root meristem activity. Plant Cel/ 15: 2532-2550.

WERNER, T., MOTYKA, V., STRNAD, M. and SCHMULLING, T. (2001). Regulation of plant growth by cytokinin. Proc. Natl. Acad. Sci. USA 98: 10487-10492.

XIE, Q., FRUGIS, G., COLGAN, D. and CHUA, N.H. (2000). Arabidopsis NAC1 transduces auxin signal downstream of TIR1 to promote lateral root development. Genes Dev. 14: 3024-3036.

XIE, Q., GUO, H.S., DALLMAN, G., FANG, S., WEISSMAN, A.M. and CHUA, N.H. (2002). SINAT5 promotes ubiquitin-related degradation of NAC1 to attenuate auxin signals. Nature 419: 167-170.

XIE, Q., SANZ-BURGOS, A.P., HANNON, G.J. and GUTIERREZ, C. (1996). Plant cells contain a novel member of the retinoblastoma family of growth regulatory proteins. EMBO J. 15: 4900-4908.

XIE, Q., SUAREZ-LOPEZ, P. and GUTIERREZ, C. (1995). Identification and analysis of a retinoblastoma binding motif in the replication protein of a plant DNA virus: requirement for efficient viral DNA replication. EMBO J. 14: 4073-4082.

YADEGARI, R. and DREWS, G.N. (2004). Female gametophyte development. Plant Cel/ 16 Suppl: S133-S141.

YANG, S.W., JIN, E., CHUNG, I.K. and KIM, W.T. (2002). Cell cycle-dependent regulation of telomerase activity by auxin, abscisic acid and protein phosphorylation in tobacco BY-2 suspension culture cells. Plant J. 29: 617-626.

YIN, Y., CHEONG, H., FRIEDRICHSEN, D., ZHAO, Y., HU, J., MORA-GARCIA, S. 
and CHORY, J. (2002). A crucial role for the putative Arabidopsis topoisomerase VI in plant growth and development. Proc. Natt. Acad. Sci. USA 99: 10191-10196.

YOSHIZUMI, T., NAGATA, N., SHIMADA, H. and MATSUI, M. (1999). An Arabidopsis cell cycle -dependent kinase-related gene, $\mathrm{CDC} 2 \mathrm{~b}$, plays a role in regulating seedling growth in darkness. Plant Cell 11: 1883-1896.

YU, Y., STEINMETZ, A., MEYER, D., BROWN, S. and SHEN, W.H. (2003). The tobacco A-type cyclin, Nicta;CYCA3;2, at the nexus of cell division and differen- tiation. Plant Cel/ 15: 2763-2777.

ZHANG, K., LETHAM, D.S. and JOHN, P.C. (1996). Cytokinin controls the cell cycle at mitosis by stimulating the tyrosine dephosphorylation and activation of p34cdc2like $\mathrm{H} 1$ histone kinase. Planta 200: 2-12.

ZHOU, Y., WANG, H., GILMER, S., WHITWILL, S. and FOWKE, L.C. (2003). Effects of co-expressing the plant CDK inhibitor ICK1 and D-type cyclin genes on plant growth, cell size and ploidy in Arabidopsis thaliana. Planta 216: 604-613. 